\title{
Pseudostellaria sierrae (Caryophyllaceae), a New Species from California
}

\author{
Richard K. Rabeler \\ University of Michigan Herbarium, 1205 N University Ave., Ann Arbor, Michigan \\ 48109-1057, U.S.A.
}

Ronald L. Hartman

Rocky Mountain Herbarium, Department of Botany, University of Wyoming, Laramie, Wyoming 82071-3165, U.S.A.

Abstract. Pseudostellaria sierrae is described as new from northern California. Glabrous stems and leaves, a V-shaped apical notch in each ligulate petal, five yellow anthers, and seeds with minute projections on each tubercle are features useful in distinguishing $P$. sierrae from $P$. jamesiana (Torrey) W. A. Weber \& R. L. Hartman, the congener widely distributed in the western United States. Pseudostellaria sierrae is found in mixed oak or conifer forests.

Key words: California, Caryophyllaceae, North America, Pseudostellaria, Sierra Nevada, Stellaria, United States.

Pseudostellaria is a genus of 16 (Bittrich, 1993) to 20 species (Rabeler, pers. compilation), all but 3 of which are restricted to Asia (Afghanistan and Siberia east to Japan and Korea). Two additional species from Korea were recently described and effectively, but not validly, published (Lee, 1998). Pseudostellaria europaea Schaeftlein occurs in southeastern Europe, while two species, P. jamesiana (Torrey) W. A. Weber \& R. L. Hartman and this novelty, are known in western North America. The chief feature distinguishing Pseudostellaria is the presence of thickened root sections, often as small tubers near the base of the stem (P. jamesiana, Weber \& Hartman, 1979) or as tuberous, cigar-like, thickened roots arising periodically along the rhizome (P. sierrae, Fig. 1). While most species of the genus have both chasmogamous and cleistogamous flowers, the North American species lack the latter. Pseudostellaria jamesiana and P. sierrae share an unusual pattern of fruit dehiscence with the six valves usually rolling back 2 or 3 revolutions, forming a shallow dish (Fig. 1C; Weber \& Hartman, 1979). This mechanism may insure the release of the 1 or 2 seeds that are quite large.
Pseudostellaria sierrae Rabeler \& R. L. Hartman, sp. nov. TYPE: U.S.A. California: Plumas Co., in litter under Pinus lambertiana, mixed oak-pine-fir forest, $150 \mathrm{ft}$. S of FS road 26N49Y, 0.9 mi. E of Plumas Co. 204 (Dixie Canyon Rd.), 1.95 mi. N of California 89, W of Crescent Mills, $40^{\circ} 06^{\prime} 24^{\prime \prime} \mathrm{N}, 120^{\circ} 55^{\prime} 45^{\prime \prime} \mathrm{W}$, T26N, R9E, sec. 14, SE 1/4, ca. 1456 m, 14 June 1997, R. K. Rabeler 1290 [with B. Ertter, T. Morosco, J. Shevock] (holotype, MICH; isotypes, GH, MO, RM, RSA, UC). Figure 1.

Herbae perennis omnino glabra; radices verticales carnosi rhizomatibus. Folia lanceolata ad elliptica marginibus integris tenuiter scariosis. Flores perfecti actinomorphi l3 per caulem vel ramum; sepala lanceolata ad anguste ovata marginibus scariosis; petala 5 , ligulata apice inciso $\mathrm{V}$-formo; stamina 5 , antherae flava; styli 3 distincti, stigmatibus quasi terminalibus. Capsule ovoidea, valvis 6 pauxillum recurvis ad arcte 2 - vel 3 -plo revolutis; semina 1 vel fortasse 2 brunneola circularia ad oblonga lateraliter complanata tuberculata aliquot tuberculis $6-12$ verrucis rubris minutis; verrucae saepe $5-8$ projecturis conicis minutis; radicula prominens.

Perennial, glabrous herb 9-27 cm tall, with stems arising singly, at varying intervals along rhizome. Roots vertical or nearly so, $5-15 \mathrm{~cm}$ long, ca. $0.3 \mathrm{~mm}$ thick near point of attachment to rhizome, enlarging to 2-3 mm thick below, fleshy; rhizomes white to tan, $0.5-2 \mathrm{~mm}$ diam., shiny, usually with 1 to several scaly buds at the nodes. Stems simple or branched, rounded, obtusely angled or grooved when pressed, internodes $1-4 \mathrm{~cm}$ long or more below, often $0.3-1 \mathrm{~mm}$ long in upper $1 / 3-1 / 2$, axillary branches 1 to $3(7), 1-5(9.5) \mathrm{cm}$ long. Leaves opposite, exstipulate, the lowest 2 to 6 and those of the rhizome rudimentary, connate for 0.5$1.5 \mathrm{~mm}, 3-8 \mathrm{~mm}$ long, the primary leaves in 5 to 10 pairs on main stem with bases weakly fused, those of the upper stem and especially branches generally much more closely spaced, narrowly lanceolate or elliptic, $0.7-3.5 \mathrm{~cm}$ long, 1-5(8) mm

Novon 12: 82-86. 2002. 


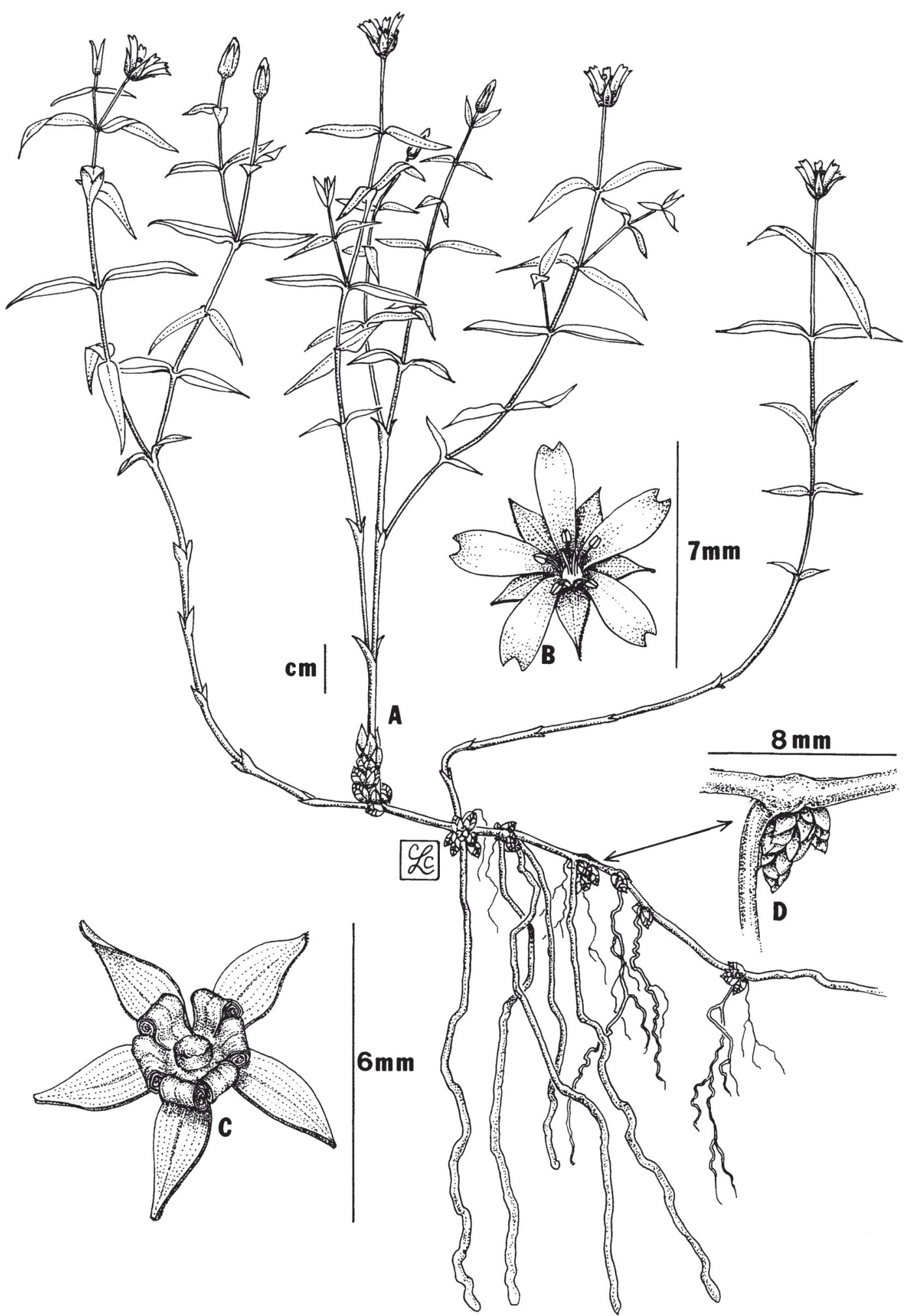

Figure 1. Pseudostellaria sierrae Rabeler \& R. L. Hartman. -A. Habit. - B. Flower. - C. Dehisced fruit with subtending sepals. - D. Rhizome segment with buds and root at node. (From holotype, Rabeler 1290, MICH.) 


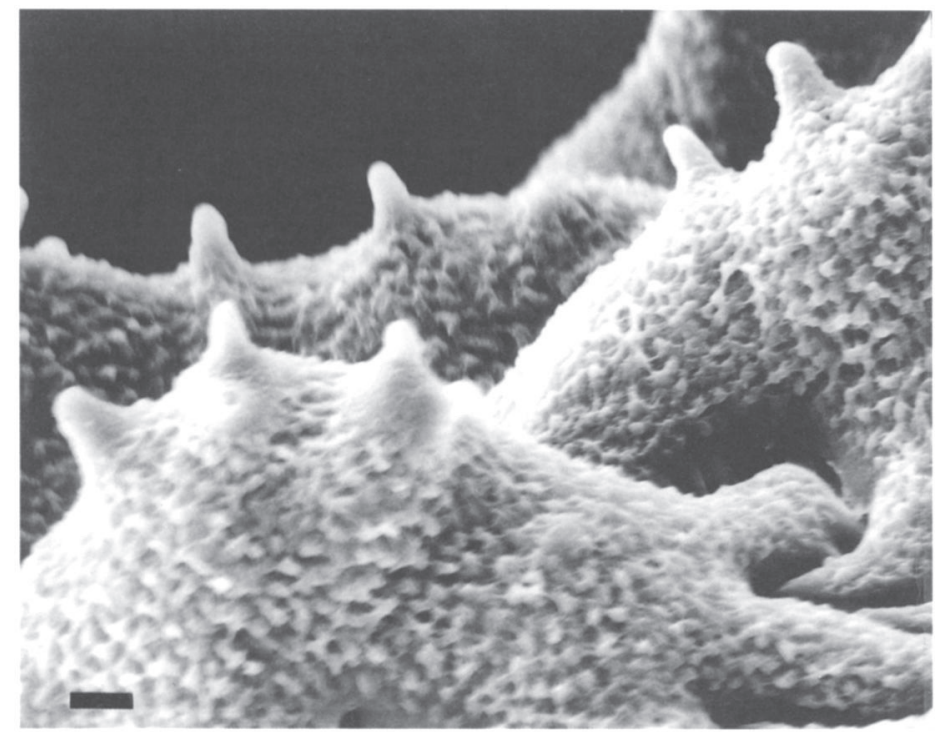

Figure 2. Scanning electron micrograph of seed of Pseudostellaria sierrae (Hartman 58546, RM) showing the minute projections on each tubercle. Scale line represents $10 \mu \mathrm{m}$.

wide, lower surface of blade finely reticulate, pustulate (30× magnification), margin entire, thinly scarious. Flowers perfect, chasmogamous, regular, solitary, terminal and axillary on main stem and often 1 or 2 (to 6) axillary branches, sometimes abortive; sepals lanceolate to narrowly ovate, 4-6.5 $\mathrm{mm}$ long, to $7 \mathrm{~mm}$ in fruit, shiny, glabrous, margins scarious, with midvein and 4 to 6 weaker veins arising from base, apex acute or acuminate; petals 5 , white, ligulate, 5-8(9) $\times 1-1.5 \mathrm{~mm}$, apex with a V-shaped notch $0.2-0.7 \mathrm{~mm}$ deep; stamens 5 , each with a circular, thickened, basal gland 2-2.5 times the filament width, anthers yellow, 0.6-0.7 mm long; styles 3, distinct, 2-3.5 mm long, stigma terminal, $0.1-0.2 \mathrm{~mm}$ long; ovary 3-carpellate; ovules 3 to 6 , most abortive. Capsule ovoid, 4-4.5 $\mathrm{mm}$ long, valves 6 , dehiscing by recurving somewhat to rolling back tightly 2 or 3 revolutions or for $2 / 3$ of length with the lower portions forming a shallow dish, exposing the basal placenta, a broad, irregular column 0.5-1 mm tall. Seeds 1, possibly 2, light brown, 3-3.4 mm long, circular to somewhat oblong, flattened laterally, radicle prominent, mature seeds with most tubercles broadly conical to elongate, rounded, interdigitating, each with 6 to 12 minute red bumps that develop into 5 to 8 conical projections ca. $0.02 \mathrm{~mm}$ long $(50 \times$ magnification).

Pseudostellaria sierrae exhibits two features that make placement within the most recent infrageneric classification (Mizushima, 1965) problematic. First, 5 rather than (8) 10 stamens appears to be unique in the genus. Mizushima (1965) divided Pseudostellaria into two sections on the basis of seed tubercle ornamentation. In section Pseudostellaria, including only $P$. rupestris (Turczaninow) Pax, the seed tubercles each end in an apically barbed glochid, while in section Mamillatae (Ohwi) M. Mizushima the seed tubercles end in a single deciduous spinule. Second, the minute conical projections from the end of each tubercle in $P$. sierrae may be an intermediate condition (Fig. 2).

The paratypes cited below include all other collections we have found. Habitat information suggests $P$. sierrae to be a plant of the woodland floor, either in mixed oak-pine or fir forests, at 1250 $1970 \mathrm{~m}$ elevation. At both sites we visited, the ground cover was sparse and mostly consisted of $P$. sierrae. All collections occur in the Northern High Sierra Nevada subregion of the California Floristic Province (Hickman, 1993), the eight localities spanning a latitudinal range of $285 \mathrm{~km}$ (Fig. 3).

Pseudostellaria sierrae may be more common than suggested by the few collections cited. In describing his efforts to locate $P$. sierrae, Lowell Ahart (pers. comm.), an experienced amateur familiar with the Bowman Lake area, stated: "Both sides of the road under Red Firs [Abies magnifica A. Murray bis] are massive stands of Pseudostellaria." Given the similarity of the range of these taxa (see Hickman, 1993, and Map 8W in Little, 1971), we suspect additional fieldwork may show $P$. sierrae occupying a somewhat larger area.

Botanists have collected $P$. sierrae occasionally 


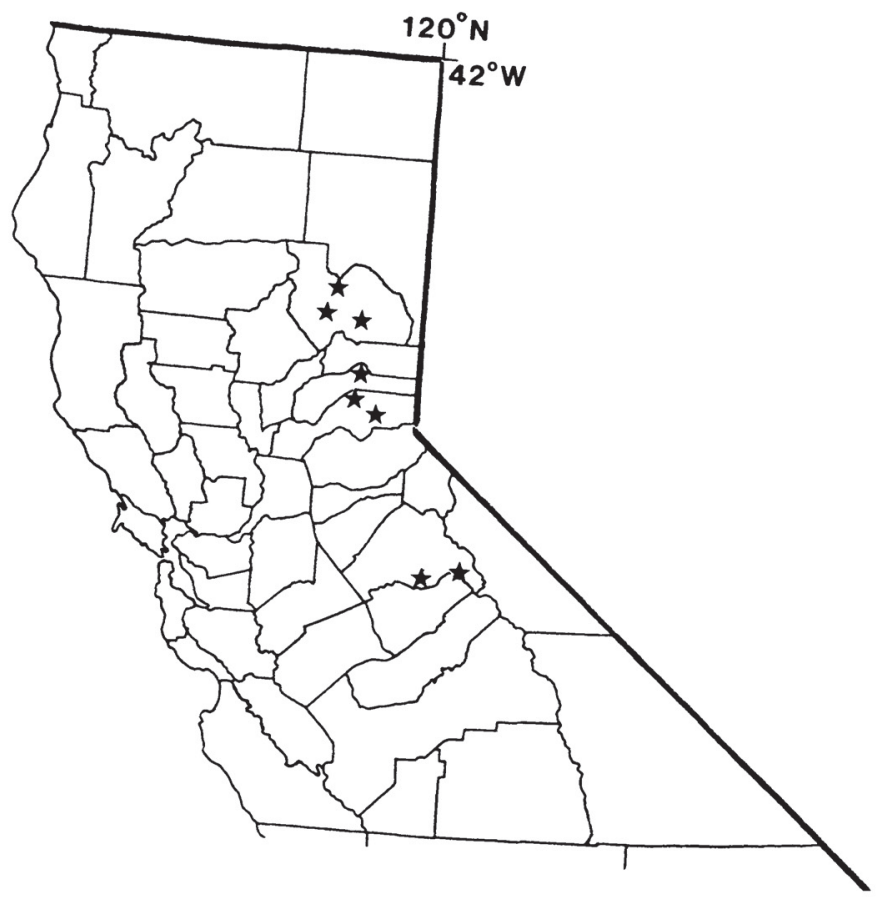

Figure 3. Distribution of Pseudostellaria sierrae. Area shown is the northern two-thirds of California.

since 1878. The most widely distributed collection prior to our own collections, M. E. Jones 3287, introduced each of the authors independently to this species. Rabeler first noticed $P$. sierrae when he received seven specimens of Jones 3287 among the loans requested for his dissertation research on the Stellaria calycantha (Ledebour) Bongard complex (Rabeler, 1986). Although they were clearly not Stellaria crispa Chamisso \& Schlechtendal, Rabeler was not able to identify them beyond "cf. Pseudostellaria?" in 1986. Hartman was introduced to Pseudostellaria sierrae via the UC specimen of Jones 3287. When the UC loan to Rabeler was returned in late 1986, Hartman was working on the Caryophyllaceae treatment for the Jepson Manual (Hartman, 1993). The UC specimen of Jones 3287 that Rabeler had annotated as "cf. Pseudostellaria" caught Hartman's eye as well as the following curatorial note: "Pseudostellaria is from Asia. File in Caryophyllaceae indet." Hartman also was unable to place it in an existing taxon.

With the exception of Jones 3287, all of the collections of $P$. sierrae identified to species we have seen have been either misidentified as Stellaria jamesiana Torrey ( $\equiv P$. jamesiana) or Arenaria macrophylla Hooker ( $\equiv$ Moehringia macrophylla (Hooker) Fenzl) or identified only to one of these genera (see Hartman, 1993, for generic delimitations). The only evidence that we have seen of pre- vious recognition of this species as new was from the USFS (at RM) sheet of Bolt's 1934 collection from Tadpole Spring. Identifying it as "Moehringia?", M. L. Bombard had penciled a series of notes on the sheet in 1939 ending with "possibly a new species." While all three taxa can be found in Sierran coniferous forests, they can be easily separated by the characters given in the following key.

Key to Pseudostellaria SIERRAE AND SPECIES WITH Which It Has Been Confused

la. Plants glabrous throughout; flowers solitary, mostly terminal; stamens 5 Pseudostellaria sierrae

1b. Plants either with dense glandular hairs (especially above) or peg-like hairs; flowers in cymes; stamens 10.

2a. Plants with dense glandular hairs (sometimes glabrous below); inflorescence bracts large, leafy; petals shallowly notched .... ........... Pseudostellaria jamesiana

2b. Plants with short, peg-like hairs; inflorescence bracts tiny, scarious; petals entire . . . . . . . . . . Moehringia macrophylla

Paratypes. U.S.A. California: Nevada Co., Truckee, May 1878, J. P. Moore s.n. (CAS); dry soil, shaded slopes below sphagnum bog, Fall Creek, just $\mathrm{E}$ of Lake Bowman Road, ca. 5 mi. N of Yuba Gap, 14 July 1965, G. H. True 2257 [with J. T. Howell] (CAS, MICH, NY); in yellow pine forest, dry rocky slope on mountain near dirt road and dry flat $\mathrm{S}$ of cement dam across Fall Creek, ca. 1/4 mi. E of Bowman Lake Road, T17N, R12E, NW $1 / 4$ of sec. 6,5600 ft., 10 Aug. 2000, L. Ahart 8650 (BRIT, CDA, CHSC, 
DAV, ID, JEPS, MICH, MSC, RM, UC, V); Placer Co., Emigrant Gap, 28 June 1882, M. E. Jones 3287 (CAS, MO, MSC, NY, POM, UC, US); timberland-chaparral, 1 mi. N of Tadpole Spring, T15N, R13E, sec. 5, $6500 \mathrm{ft}$., 19 July 1934, B. Bolt s.n. (USFS at RM) but B. Bolt 146 (UC); under sparse canopy of Abies magnifica, especially common in shaded areas or along large logs in the drip zone, often forming a monoculture, near campsite, ca. 200 yards from Foresthill Road, 2-2.5 road mi. W from Sailor Flat trail turn-off, T15N, R13E, sec. 5 , ca. $6500 \mathrm{ft} ., 11$ July 1997, R. L. Hartman 58546 (BRY, CAS, COLO, MICH, NY, RM, US); Plumas Co., rocky hillside, Grizzly Ridge, 6500 ft., 29 June 1919, W. W. Wagner s.n. (DS); forest of mixed conifer, oak, maple, $\mathrm{E}$ side of mountain above Crescent Mills, E of Round Valley Reservoir, T26N, R9E, sec. 23, ca. 4500 ft., 14 May 1990, B. Ertter 8984 [with G. Schoolcraft] (OSC, RM); shaded slopes in coniferous forest surrounding Snake Lake, $39^{\circ} 58^{\prime} \mathrm{N}, 120^{\circ} 59^{\prime} \mathrm{W}$, 1250 m, 30 May 1993, G. F. Hrusa 11139 \& E. Sandoval (CDA, JEPS); Tuolumne Co., Tioga Road, 6 June 1951, H. \& M. Dearing 6923 (SBBG); Gin Flat near Yosemite Valley, June 1964, M. Ackley s.n. (CAS).

Acknowledgments. We thank David J. Keil for assistance with the Latin description; Barbara Ertter (UC) for hospitality and logistics support in arranging the expedition for Rabeler to collect the type; James R. Shevock and Kathy Van Zuuk (U.S. Forest Service) for arranging appropriate permitting for Rabeler and Hartman, respectively; Larry Janeway (CHSC) for introducing the plant to Lowell Ahart and for forwarding his collection and correspondence to MICH; Greg Brown for assistance with the SEM photo; and Carolyn Crawford for the illustration. We also thank the curators of CAS,
MO, RSA/POM, SBBG, and UC/JEPS for hospitality during visits by Rabeler and/or Hartman and CAS, CHSC, DAV, F, GH, HSC, MO, MSC, NSMC, NY, RENO, RSA/POM, SBBG, UC/JEPS, and US for loans to MICH (all) or RM (UC) for this study.

\section{Literature Cited}

Bittrich, V. 1993. Caryophyllaceae. Pp. 206-236 in K. Kubitzki, J. G. Rohwer \& V. Bittrich (editors), The Families and Genera of Vascular Plants. II. Flowering Plants, Dicotyledons, Magnoliid, Hamamelid and Caryophyllid Families. Springer-Verlag, Berlin.

Hartman, R. L. 1993. Caryophyllaceae (except Silene). Pp. 475-489, 493-497 in J. C. Hickman (editor), The Jepson Manual: Higher Plants of California. Univ. California Press, Berkeley.

Hickman, J. C. 1993. Geographic subdivisions of California. Pp. 37-46 in J. C. Hickman (editor), The Jepson Manual: Higher Plants of California. Univ. California Press, Berkeley.

Lee, Y. N. 1998. Flora of Korea, 3rd rev. ed. Kyo-Hak Publishing, Seoul.

Little, E. L., Jr. 1971. Atlas of United States Trees, Vol. 1. Conifers and Important Hardwoods. U.S.D.A. Forest Serv. Misc. Publ. 1146.

Mizushima, M. 1965. Critical studies on Japanese plants, 11: The genus Pseudostellaria Pax in Japan. Bull. Bot. Surv. India 7: 62-72.

Rabeler, R. K. 1986. Revision of the Stellaria calycantha (Caryophyllaceae) Complex and Taxonomic Notes on the Genus. Ph.D. Dissertation, Michigan State University, East Lansing.

Weber, W. A. \& R. Hartman. 1979. Pseudostellaria jamesiana, comb. nov., a North American representative of a Eurasian genus. Phytologia 44: 313-314. 